\title{
The Role of the International Labor Organization in the Human Resource Management System
}

\author{
Abdurakhmanov Kalandar Khodzhaevich, Kudbiev Sherzod Davlyatovich, Magroupov Aziz Yuldashevich
}

\begin{abstract}
Annotation. Human resources management is currently carried out at all levels: from structural units of the organization to government levels. The main recommendations in the field of human resource management were developed by the International Labor Organization. The main provisions of the ILO are aimed at creating relationships between various parties of the labor process, maintaining normal and safe working conditions in the workplace. In any state has its own system of government bodies dealing with social policy, employment management and labor relations. In the Republic of Uzbekistan, at present, the Ministry of Employment and Labor Relations functions as part of the Government. The article presents the formation of an effective human resource management system. Currently, in science and in the practice of human resource management, various concepts are distinguished to denote the participation of people in the labor process, such as labor resources, labor force, human resources, labor potential, and human resources. Due to the fact that the development of theoretical and practical knowledge about managing people is of an evolutionary nature, the system of views on methods and methods of management was formed as society's perception of the values and needs of people developed.
\end{abstract}

Keywords.Human resources, international labor organization, working conditions, jobs, management system, management methods, labor market, human potential.

\section{INTRODUCTION}

The existing human resource management system in the national labor markets in the global economy involves coordinating activities from supranational structures. The range of problems facing structures of this kind is very wide.

Revised Manuscript Received on July 25, 2019

Abdurakhmanov Kalandar Khodzhaevich, Academic of the Academy of Sciences of the Republic of Uzbekistan, Doctor of Economics, Professor, Republic of Uzbekistan, 100003, Tashkent Islam Karimov, 49, building 7, KAbdurakhmanov@yandex.ru Тел.:+998901855707

Kudbiev Sherzod Davlyatovich, Scientific applicant of the department "Economics and Sociology of Labor", Tashkent State University of Economics, Republic of Uzbekistan, Republic of Uzbekistan, 100100, Tashkent city, Mirabad district,, St. Mirabad, 15, + 998 (71) 23941-21

Magroupov Aziz Yuldashevich, Scientific applicant of the department "Labor Economics and Management", Tashkent Branch of the Russian Economic, University. G.V. Plekhanov
One of the first organizations involved in international labor issues was the International Labor Organization. Since the process of human resource management on a global scale is an extremely heterogeneous process. The presence of a global regulatory organization allowed for greater harmonization of processes in this area. Another reason for the need to create such an institution at the beginning of the XX century. there was a need to maintain peace based on the principles of social justice in all countries.

In essence, the ILO is the only tripartite international organization that provides communication between representatives of government organizations, employers and workers. This structure makes the ILO a unique forum where government structures and social partners in member countries can freely and openly discuss and improve standards and policies in the field of labor and labor relations.

At present, the ILO also provides comprehensive support to workers around the world, including in the Republic of Uzbekistan, developing conventions and recommendations that guarantee the basic rights of workers, primarily to the freedom of labor organizations, collective bargaining, equality of opportunity and treatment, and the elimination of forced labor.

The International Labor Organization presented a report prepared on behalf of the World Bank, which provides an independent assessment of the measures taken by the Government of Uzbekistan to eliminate child labor and forced labor during the cotton harvest. The report notes that measures are being taken in the country to end the practice of forced labor, and the use of child labor has been completely stopped.

The report is based on an analysis of more than 3 thousand interviews, which were attended by cotton pickers from among 2.6 million workers across the country. The results of the study suggest that there are a number of significant changes in the cotton industry, aimed at ensuring fundamental labor rights.

Cotton harvest in 2017 was held in conditions of prevalence of publicity and dialogue. This applied to all groups of civil society, including individual critical activists. At the same time, at the regional and district level, they still do not have time to assimilate and execute a huge number of decrees and resolutions issued by the government of the country.

The results of the monitoring carried out by the ILO show that of the 2.6 million cotton pickers, most of the workers worked voluntarily. The document also confirms that the systematic use of child labor in cotton harvesting is no longer observed, but the situation must be controlled

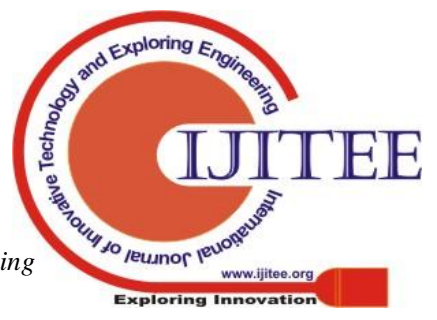




\section{The Role of the International Labor Organization in the Human Resource Management System}

so that children continue to go to school.

Uzbekistan has already introduced a number of measures to eliminate violations in the field of labor rights. For example, since September 2017, at the initial stage, the elimination of risk groups, which include students, education and health care workers, has been excluded. The country also increased wages to cotton pickers in accordance with the recommendations of the ILO and the World Bank.

Speaking at a session of the UN General Assembly in New York in September 2017, President of Uzbekistan Shavkat Mirziyev noted that the country would give up forced labor and reaffirmed the commitment of his government to cooperate with the ILO.

"Our goal is to strengthen the mechanisms that make the power of the people in the country not nominal, but real. We are deeply convinced: not the people should serve the state bodies, but the state bodies should serve the people. In cooperation with the International Labor Organization, effective measures have been taken to eliminate child and forced labor "(https://president.uz/ru/lists/view/1063, 2017).

Thus, the priority measure to prevent the use of forced labor in the Republic of Uzbekistan are:

1) strengthening social partnership in Uzbekistan in order to implement fundamental principles and rights at work, including national policies for the application of international labor standards, an action plan for the application of conventions on forced and child labor, working conditions in agriculture, including in cotton growing, strengthening the capacity of trade unions and employers, the development of tripartite institutions of social dialogue;

2) expanding opportunities for decent employment, including the implementation of active policies to ensure full, productive and freely chosen employment, including youth, the effective functioning of labor market institutions, the development of entrepreneurship by promoting selfemployment and supporting small business;

3) improvement of working conditions and social protection of the population, including the development of an effective system of labor protection management, collective bargaining and tripartite consultations on wage issues, strengthening social protection of the population.

Human resources management is currently carried out at all levels: from structural units of the organization to government levels. The main recommendations in the field of human resource management were developed by the International Labor Organization. The main provisions of the ILO are aimed at creating relationships between various parties of the labor process, maintaining normal and safe working conditions in the workplace. In any state has its own system of government bodies dealing with social policy, employment management and labor relations. In the Republic of Uzbekistan, at present, the Ministry of Employment and Labor Relations operates within the Government for solving such tasks. In the regions of the republic there are also human resource management bodies dealing with issues of social policy, employment of the population, regulation of relations between employees and employers.

Many areas of labor relations that were specified during the creation of the organization remain relevant to this day. Among them:

- regulation of working time, including the establishment of its maximum duration;
- regulation of the supply and demand of labor, preventing unemployment, ensuring a decent standard of living;

- protection of workers from industrial injuries, diseases, etc ;

- protection of children, youth and women, consideration of their interests in labor relations;

- recognition of the principle of equal pay for equal work;

- recognition of the principle of freedom of association, etc.

Thus, the ILO recommendations are primarily aimed at ensuring normal working conditions and creating constructive relationships between employers, employees and the state. Countries that implement ILO recommendations are recognized in international relations and have priorities in the allocation of international funds.

\section{LITERATURE REVIEW}

For the formation of an effective human resource management system, a detailed study of historical and modern ideas about labor is necessary. Currently, in science and in the practice of human resource management, various concepts are distinguished to denote the participation of people in the labor process, such as labor resources, labor force, human resources, labor potential, and human resources.

Zhuravlev P.V. identifies the concepts of "labor", "personnel", "personnel" and "human resources" and defines human resources in the editorial office "treating people as the main asset of any organization" (OdegovY.G. and others, 2017).

According to Krasnozhenova G.F., Simonina P.V. "Human resources is a concept reflecting the main wealth of any society, the prosperity of which is possible when creating conditions for production, development, use of this resource, taking into account the interests of each person" (Krasnozhenova GF et al., 2008).

The main wealth of any society is people, and the ultimate criterion of economic and social progress is a measure of human development and satisfaction of its needs. The processes of dynamic development and rapid renovation of the technological basis of modern society causes a profound transformation of all its aspects, leading to a change in the place and role of man in the socialreproduction process and the new way of life of people. The concept of "human capital" is intensively used by the world economic science, which appreciated the role of intellectual activity, found out the necessity and high efficiency of investments in a person. (Abdurakhmanov K.Kh. 2014).

Generally, the concept of human resources can be represented as a structured set of human potential, its personal qualities, workforce and human capital. A. Smith considered that "an increase in the productivity of useful labor depends, first of all, on increasing the worker's dexterity and skills, and then on improving the machines and tools with which he worked." Also, the importance of human-oriented management was emphasized by R. Owen, who argued that "his workers - living machines" - are just as important for a factory as "non-living machines" and also need to be cared for "(Owen R., 1975).

Human resources management as an integral function is intended to 
maximize the efficiency of staff in serving the strategic goals of the employer. Primarily focuses on managing people in organizations, highlighting them as the dominant policy in the human resource management system (Collings D.G. et al., 2009).

In organizations, usually in departments and divisions, HRM is assigned to line managers. HRM includes a number of activities, including payments to employees for participation in projects, training and development, additional certification and re-certification, for awards from public organizations (Paauwe J. et al., 2009).

Due to the fact that the development of theoretical and practical knowledge about managing people is of an evolutionary nature, the system of views on methods and methods of management was formed as society's perception of the values and needs of people developed. Theories of managing people as a type of activity went through several periods in their development (Table 1).

Table 1.

The evolution of human resource management concepts

\begin{tabular}{|c|c|c|c|}
\hline Historical period & Concept name & Postulates & $\begin{array}{l}\text { Distinctive feature of } \\
\text { management }\end{array}$ \\
\hline $20-40 \mathrm{~s}$ & HR management & $\begin{array}{l}\text { A person acts as a carrier of labor, low } \\
\text { skilled labor prevails. }\end{array}$ & $\begin{array}{l}\text { Hiring and firing employees, } \\
\text { payroll. }\end{array}$ \\
\hline $50-70 \mathrm{~s}$ & Control & $\begin{array}{l}\text { Orientation, both on the tasks of } \\
\text { production and on the person, the need } \\
\text { for professional knowledge and skills. }\end{array}$ & $\begin{array}{l}\text { Socio-psychological } \\
\text { assistance, staff } \\
\text { development, training and } \\
\text { retraining. }\end{array}$ \\
\hline C 80-s & by staff & $\begin{array}{l}\text { A person is the most important } \\
\text { resource, both organizations and society } \\
\text { as a whole, the intellectual and cultural } \\
\text { qualities of the worker dominate. }\end{array}$ & $\begin{array}{l}\text { Personnel regulation system } \\
\text { and strategic development of } \\
\text { human resources. }\end{array}$ \\
\hline
\end{tabular}

In this evolutionary path can be noted the change of the three concepts of personnel management, which is caused by economic, social and technical changes in society. The origins of the concept of human resource management are deep in human history. After analyzing the process of development of society, we can consider the most significant stages in the development of approaches to human resource management. The concept of human resource management, according to Zhuravlev, $\mathrm{PV}$, is "the result of applied and basic research, including developments in related fields of knowledge" (Zhuravlev, PV, et al., 2002).

Since the 20s. In the twentieth century, many scientists participated in the development of the labor economics; together, great success was achieved in solving these problems. The birth of the classical (administrative) school of management began, which contributed to the beginning of the transition to human resource management. Their representative is A. Fayol. The basis of A. Fayol's work "General and Industrial Management" is that there are two organisms in any enterprise: material and social, i.e. the totality of labor, the means of labor and the objects of labor and the relations of people in the labor process (Fayol H., 1917).

This relationship was the subject of research A. Fayol. Thus, he tried to substantiate the need for and the possibility of creating a special science of managing people, as part of a general teaching on enterprise management. They were also the first to propose a classification of the personnel of an industrial enterprise and with the help of special "installations" tried to express requirements for each classification group (Fayol H., 1917).

An important role in the development of the theory of human resources was made by $M$. Weber, who highlighted the important principles of personnel management of state enterprises (Weber M., 2003):
- clear definition of job responsibilities;

- compliance with the level of official relations;

- unquestioning observance of the rules of management activities;

- selection of candidates in accordance with the required professional knowledge;

- increase in labor productivity due to the impersonal performance of duties;

- assessment of the competence of workers through certification.

As an example of a scientific approach to the study of human resource management, one can consider the work "Research on employee trust: epistemological foundations and paradigmatic boundaries" (Siebert S. et al., 2016). It examines the epistemological roots and paradigmatic frontiers of research on the trust of employees, growing in the field of human resource management. Using the concept of paradigmatic relations as relations of different qualities (Tsvetkov V. Ya., 2016), the concept of the "target employee" of an organization was identified in order to study its strengths and weaknesses. A review of the literature in the work (Siebert S. et al., 2016) about employee confidence showed that most of the articles on this subject are written from a psychological point of view. They are characterized by a positivist methodology, a theory of dispersion and a quantitative theory of data collection.

Considering the antecedent theoretical developments in the field of human resource management, it can be noted that human resources research evolved from the ideas of Robert Owen and Charles Babbage during the industrial revolution. They found that people play a crucial role in the success of the organization. They expressed the opinion that the wellbeing of the staff led to perfect work. "Without healthy workers, an organization cannot

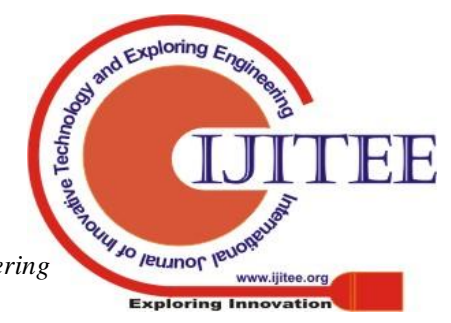




\section{The Role of the International Labor Organization in the Human Resource Management System}

survive" (Griffin R., 2007).

Also no less important contribution to the development of the concept of human resources management was made by D. MacGregor, the author of the theory " $\mathrm{X}$ " and "Y". In accordance with the theory of "X" every person needs to be forced, otherwise the employee will always strive to evade from duties. Management methods based on this theory have an extensive way, which is associated with high costs to combat changing economic conditions (Sheldrake D., 2005).

The behavioral approach became very popular in the 60s. in the field of personnel management. The ideas of representatives of this approach were based primarily on interpersonal relations, which helped to help employees realize their potential. (Made in America, 1974) Subsequently, the theory of "Y" in 1981, V. Ouchi developed the theory of " $Z$ " based on the Japanese model of control. In contrast to the theory of "Y", it also considers philosophical approaches to management, and participatoryness is the basis for the growth of labor productivity (Theory Z., 1981).

At present, the system empiricist school has become widespread. A striking example of the work of this school is the system model "7-C". The organization of management in this model is based on the basis of seven interrelated parts that have a high dependence on the change of each component: strategy, structure, system, staff, style, qualification, and value sharing. The main objective of the modern concept of human resource management is the feasibility of economic investments in personnel for its training, advanced training, identifying its potential and disclosing abilities.

Human resource management, as a scientific area, was formed as a combination of management, sociology, psychology, economics, labor law, and many other sciences. According to Graham H.T., Bennett R., "human resource management is the human aspect of enterprise management and the attitude of workers with their companies" (Graham H.T. et al., 2003).

Armstrong $M$. defines human resource management "as a strategic and coherent approach to managing the most valuable asset of an enterprise: people working there who collectively and individually contribute to the solution of enterprise problems" (Armstrong M., 2004).

We can single out the main strategic functions of human resource management: balancing human resource management and enterprise business strategy; reengineering organization processes; information interaction with employees of the organization, change management (Ulrich D., 1996). At the macro level, human resource management is responsible for overseeing organizational leadership and management culture. Human resource management ensures compliance with employment and labor laws, which may differ in spatial characteristics. The functions of human resource management include health and safety oversight. In cases where employees are willing and legally allowed to enter into a collective bargaining agreement, HR, as a rule, also serves as the company's main link with representatives of trade unions. This goes beyond standard staffing.
Generally, human resource management can be represented as strategic and operational management, aimed at improving the efficiency of the use of human resources of the organization.

The basic principles of human resource management are:

- man is the main factor in the effectiveness of the organization and its competitiveness;

- the feasibility of investing in human resources;

- improving the quality of working life;

- systematic training and staff training;

- a strategic approach to human resource management;

- focus on the technique of group work;

- high professionalism of management personnel.

Thus, in modern conditions the systematization of theoretical knowledge in the field of human resource management is necessary for the most effective and rational use of them. The historical development of the concept of personnel management confirms the need for professional and social development of human resources for the effective functioning of the enterprise.

\section{RESULTS.}

At the present stage of market reforms, characterized by the liberalization of the economy, in the Republic of Uzbekistan, special attention is paid to improving the public administration system, including human resource management. Reforms in this area should take into account the mentality of the Uzbek people, which is characterized by hard work, a heightened sense of social justice, high spirituality, etc. In many ways, these traits were formed under the centuries-old influence of the practice of everyday life.

At the same time, an in-depth and comprehensive study of the achievements of foreign countries, while taking into account the experience of previous generations, opens up the opportunity to better understand the potential of the people of the Republic of Uzbekistan and form an effective model of human resource management.

However, to successfully solve this problem in a short period is impossible, because it is a complex process that requires a certain time, thorough variant study, starting from its initial stage and ending with the achievement of the final result. At the same time, it is impossible not to take into account that the human factor as a factor of production cannot be equated to others, because we are talking about a person who cannot be manipulated as inanimate objects. The methods of human resource management are so varied and cannot be transferred from one country to another as easily as production methods or information systems.

At the same time, it should be noted that the human resource management system in the Republic of Uzbekistan itself already has some of its own characteristic features. We can say that it absorbed the positive features of both Japanese and American, and European schools, while taking into account the peculiarities of the national mentality. Thus, it can once again be emphasized that Uzbekistan, using the wellknown international experience in building human resource

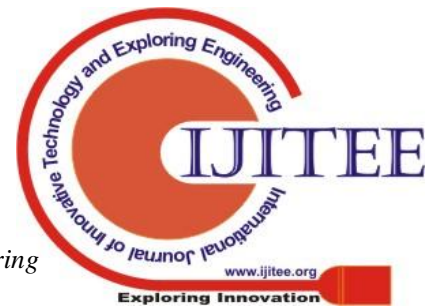


management systems, has already progressed sufficiently along the path of implementing its own national management model in this area.

In Uzbekistan, measures are being implemented within the framework of the implementation of the relevant conventions of the International Labor Organization, ratified by the republic, and awarenessraising work among the population on the principles of international and national labor standards.

The country has a Coordinating Council on Child Labor, which includes representatives of a number of government and public organizations. Plans are underway to further improve the work of the Coordination Council. In particular, the adoption of new measures aimed at the implementation of national and international labor standards is expected. In addition, work is continuing on strengthening the institutional capacity of labor inspections in the republic. Special attention is paid to raising public awareness and strengthening employers' responsibility in the implementation of ILO conventions. "Measures are being taken to improve the mechanisms of feedback, the opening of call centers in the regions, explanatory work among citizens.

International experts note the importance of promoting the positive experience of Uzbekistan's cooperation within the framework of tripartism, where thanks to the effective cooperation of the government, trade unions and employers ' organizations it is possible to achieve significant results within the framework of social and labor relations.

In Uzbekistan, the formation and active development of the labor market has led to the emergence of a significant part of workers and professionals needs for a higher level of education, a change of specialties or training. Among the special tasks of the reforms was the problem of creating a critical mass of professionals who understand the mechanisms of market relations and realize the reality of the transition to the market. Thus, the transition to the market required the renewal and realization of the potential of human resources.

It should also be noted that the most important task of market reforms is to increase the efficiency of the economy, and the main way to solve it is to increase the employee's interest in the results of their work. Practice has shown that without the inclusion of market mechanisms to achieve this goal is impossible. The formation of a complex of market relations in the field of labor is associated with a change in the priorities of state policy, in particular, the recognition by the state of the employee's ownership of their labor.

The efficiency of labor of workers, the development of the consumer market, and, consequently, production, mainly depends on the level of wages, which form the basis of the level of income of the population. If wages are high enough, the efficiency of labor increases, the purchasing power of the population increases, which stimulates the development of production. With low wages, the interest of workers is lost, the turnover of personnel, especially highly qualified, increases. In the end, this leads to a decrease in the professional level of personnel, labor productivity and as a result will lead to a deterioration in the quality of products.

In General, given that the modern market economy puts forward more and more requirements for the state of human development, and the creation of conditions for this should contribute to the further development of Uzbekistan and its economic potential.

Thus, human resources management in Uzbekistan should be aimed at the development of human capital, i.e. the improvement of the level of education, moral culture of the population, professional and creative potential, ensuring decent living conditions and strengthening health, which is the most important conditions for achieving a high level of socio-economic development of any country. The very same theory of "human resources" can find its application in Uzbekistan, taking into account the national characteristics and traditions inherent in the Uzbek people.

Measures are being taken to improve feedback mechanisms, open call centers in the regions, and raise awareness among citizens.

International experts note the importance of promoting a positive experience of interaction between Uzbekistan within tripartism, where, thanks to effective cooperation of the government, trade unions and employers' organizations, it is possible to achieve significant results in the framework of social and labor relations.

In Uzbekistan, the formation and active development of the labor market has led to the emergence of a significant part of workers and specialists in higher levels of education, in a change of specialties or in advanced training. The problem of creating a critical mass of professional cadres who understand the mechanisms of market relations and are aware of the reality of the transition to the market was also among the special tasks of the reforms. Thus, the transition to the market required updating and realizing the potential of human resources.

It should also be noted that the most important task of market reforms is to increase the efficiency of the economy, and the main way to solve it is to increase employee interest in the results of their labor. Practice has shown that without the inclusion of market mechanisms, achieving the goal is impossible. The formation of a complex of market relations in the sphere of labor is associated with a change in the priorities of state policy, in particular, recognition by the state of the employee's right to own his work force.

The efficiency of labor of workers, the development of the consumer market, and, consequently, production, mainly depends on the level of wages, which basically form the income level of the population. If the wages are high enough, then the efficiency of labor increases, the purchasing power of the population increases, which stimulates the development of production. At low wages, the interest of workers is lost, the turnover of staff, especially highly qualified ones, increases. In the end, this causes a decline in the professional level of staff, labor productivity and, as a result, will lead to a deterioration in the quality of products.

In general, taking into account that the modern market economy makes new and new requirements for the state of human development, and the creation of conditions for this should contribute to the further development

Uzbekistan and economic potential.

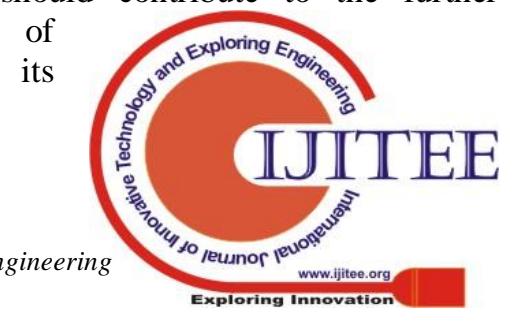




\section{The Role of the International Labor Organization in the Human Resource Management System}

Thus, human resources management in Uzbekistan should be aimed at developing human capital, that is, raising the level of education, moral culture of the population, professional and creative potential, ensuring decent living conditions and improving health, which are the most important conditions for achieving a high level of social economic development of any country. The very theory of "human resources" can find its application in Uzbekistan, taking into account the national characteristics and traditions inherent in the Uzbek people.

\section{DISCUSSION.}

The economic reforms carried out in the Republic of Uzbekistan aimed at forming market relations radically change the development of various industries and the status of the national economy as a whole. The presence of enterprises differing in size and types of activity leads to the formation and development of new economic and legal relations. In turn, this affects the relations between people, as a result of which their views are radically changed with respect to property, the results obtained and their effectiveness. These processes are associated with socio-economic development, the achievement of which depends on providing the population with work, and, above all, with the effective management of human resources.

The importance of human resources at the micro level is determined by their role in the company (organization) and participation in production. As you know, human resources are a key factor of production, and all resources that generate it are directly controlled by this factor. The role of human resources in the economy of individual regions and regions reflects its importance at the meso-level. Where human resources are high, industry, manufacturing, socio-economic infrastructure and communications are developing. The value of human resources at the macroeconomic level is based on their role in the economy of the country as a whole and its recognition as one of the main benefits. As a result of labor, tangible and intangible assets are created in the country. And the subjects of this work are people themselves, i.e. human resources. Thus, the importance of human resource management at all levels determines the scientific and economic importance of this study.

We comprehensively studied the theoretical aspects of human resource management, their formation and features, as well as their rational and effective use. In our opinion, human resources are the part of the workingage population of the country that are able to produce tangible results with the help of their psychophysical and mental abilities. They include not only the economically active population, but also those who are currently not working and looking for work, including those who are out of production, in particular, students of educational institutions. Thus, in economics and human resource management, it covers people who work and those who are not working, but can work.

It should be noted that human resources differ from each other in their specifics. Key features are as follows:

First of all, human resources are people of a certain age. They are distinguished by their qualifications, intellectual potential, experience and knowledge. This difference affects their performance (performance of work, provision of services);

Secondly, human resources not only create material benefits, but also consume them. The level of consumption depends on the efficiency of labor. Because how effectively people work, so much more income they receive, and as a result, their consumer ability also increases;

Thirdly, the material and spiritual needs of people also differ from each other. Due to differences in human resources - gender, age, health, marital status, level of education, and other social, psycho-physiological qualities - the consumption ability of consumption also varies;

Fourth, the possibilities of creation, like the needs of human resources, are unlimited. Therefore, for their effective use requires the use of various incentives. This, in turn, is a very complex process that requires complete understanding and comprehensive analysis;

Fifthly, due to the dissimilarity of labor resources, an individual approach to each person is required. Taking into account the fact that not all priority human needs can be realized, for the effective use of their labor it is important to try to meet the needs of each individual. In other words, the successful development of the country's economy necessitates a harmonious combination of human and economic interests in all processes that will be implemented to ensure the effective functioning of a complex economic mechanism of human resource management.

\section{CONCLUSION.}

In the context of the modernization of the country's economy and a radical renewal of the economy, it is advisable to implement the following measures to improve the efficiency of human resource management:

- modernization of the labor market for more efficient use of ever-increasing human resources;

- improvement of the labor market in the country on the basis of market principles, paying special attention to the transition to the policy of effective employment and the creation of new jobs for highly qualified personnel;

- the creation of the integration of labor between local executive bodies, state and economic management bodies, educational institutions, self-government bodies of citizens and the general public;

- training and professional development of personnel in enterprises and organizations, improvement of financial and moral methods of stimulating labor resources based on market principles, etc.

\section{REFERENCES}

1. Abdurakhmanov K., Zokirova N. (2014) Human development. Textbook. Bremerhaven-2014. P.423

2. Abdurakhmanov K.H. Zokirova N.K., Islamov B., Hiwatari M. (2016) Systemic transformation and sustainable human development: the Case of Uzbekistan. Jakarta: Gunadarma Publisher, 2016, p. 230.

3. Abdurakhmanov K.H. Zokirova N.K. (2013)Labour economics and sociology. Tutorial. Jakarta.:Gunadarma Publisher, 2013, 430 p..

4. Asaliev A.M., Vukovich G.G., Kirillova OG, Kosareva E.A. (2015) Evaluation of personnel in the organization: Tutorial. 
Electronic resource, 2015

5. Armstrong M. (2004) The practice of human resource management. 8th edition / Trans. from English by ed. S.K. Mordov ina. - $\mathrm{SPb}$.: Peter, 2004. - $832 \mathrm{p}$.

6. Weber, M. (2003) Political Works, 1895-1919= Gesammelte Politische Schriften, 1895-1919 / Trans. with him. B. M. Skuratova; afterword T. A. Dmitrieva. - M .: Praxis, 2003.

7. Graham H.T., Bennett R. (2003) Human Resource Management: Proc. manual for universities / Per. from English by ed. T.Yu. Bazarova and B.L. Eremina. - M .: UN ITI-DANA, 2003. - 598 p.

8. Griffin R. (2007) Principles of Management, 2007. http://www.goodreads.com/book/show/ 7453686principles-of-management.

9. Ehrenberg R.G., Ronald G. (2012) Modern labor economics: theory and public policy / Eleventh ed. Prentice Hall. 2012. $650 \mathrm{p}$.

10. Zhuravlev P.V. , Odegov Yu.G., Volgin N.A. (2002) Human Resource Management: The Experience of Industrialized Countries: Proc. allowance. - M .: Izd-vo obs amen, 2002. $448 \mathrm{p}$.

11. Krasnozhenova GF, Simonin P.V. (2008) Human Resource Management: Textbook. - M .: INFRA-M, 2008. - 159 withMade in America (1974) (under Japanese management) // Harvard Business Review. 1974;

12. Odegov Y.G., Gliakhmedov R.A., Abdurakhanov K.H. (2017) Human resource marketing. Monograph. UniversitasGyor Nonoprofit Kft. 2017. - p.262.

13. Odegov Yu.G., Abdurakhmanov K.Kh., Kotova L.R. (2011) Evaluation of the effectiveness of work with staff: Teaching aid. - M .: Alfa-Press Publishers, 2011. - 752 p.

14. Owen Robert (1969) / Nemanov I.N. / Otomi - Plaster. - M.: The Soviet Encyclopedia, 1975. - (The Great Soviet Encyclopedia: [in 30 t.] / Ch. Ed. AM Prokhorov; 19691978, v. 19).Paauwe J., Boon C. (2009) Strategic HRM: A critical review // Human resource management: A critical approach / D. G. Collings, G. Wood (Eds.). - London: Routledge, 2009. P. 38-54

15. Collings D. G., Wood G. (2009) Human resource management: A critical approach // Human resource management: A critical approach / D. G. Collings, G. Wood (Eds.). - London: Routledge, 2009. P. 1-16.

16. Siebert S., Martin G., Bozic B. (2016) Research into employee trust: epistemological foundations and paradigmatic boundaries // Human Resource Management Journal. 2016. Vol. 26. Iss. 3. P. 269- 284.

17. Type Z (1978) Organization: Stability in the Midst of Mobility // Academy of Management Review. 1978;

18. Theory Z (1981) How American Business Can Meet the Japanese Challenge. 1981.

19. Ulrich D. (1996) Human Resource Champions. The next agenda for adding value and delivering results. - Boston, Mass.: Harvard Business School Press, 1996.

20. Fayol H., (1917)Administration industrielle et générale. Paris. — Dunod et Pinat. - 1917. - 174 p.

21. 21. Tsvetkov V. Ya. (2016) Paradigmatic and syntagmatic relations in informational educational structures // Distance and virtual learning. 2016. No. 10. P. 43-50.

22. 22. Sheldrake, D. (2005) Douglas Mac-Gregory, The Human Side of an Enterprise. Pub: Aspect Press. Textbooks for universities, 2005 